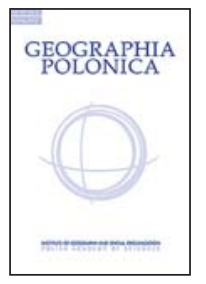

\title{
REVIVING VILLAGES - A PROPOSAL FOR A CONCEPT AND IDENTIFICATION. A METHODOLOGICAL APPROACH
}

\section{Agnieszka Latocha ${ }^{1}$ (D) Robert Szmytkie ${ }^{1}$ - Dominik Sikorski ${ }^{1}$ (ID - Przemysław Tomczak ${ }^{1}$ (D) Katarzyna Kajdanek ${ }^{2}$ (ID $・$ Paulina Miodońska $^{1}$ (ID}

\author{
${ }^{1}$ Institute of Geography and Regional Development \\ University of Wrocław \\ PI. Uniwersytecki 1, 50-137 Wrocław: Poland \\ e-mail: agnieszka.latocha@uwr.edu.pl (corresponding author) \\ ${ }^{2}$ Institute of Sociology \\ University of Wrocław \\ Koszarowa 3, 51-149 Wrocław: Poland
}

\begin{abstract}
The methodological paper proposes a new concept of a reviving village and research methods to identify it. "Reviving" entails various symptoms of increasing intensity in socio-economic processes in areas which have long been in decline, and have been classified as problem regions with signs of marginality and peripherality. To identify the reviving villages we used a combination of diverse datasets and sources of information (i.e. statistical databases, cartographic materials, field research). We critically assessed the available data pointing out to its limitations. The new methodology was tested in the borderland of the Kłodzko region in the Sudetes Mountains (Poland). Proposed research procedure can be applied to any other marginal, depopulating rural areas to identify their potential current transformations.
\end{abstract}

\section{Key words}

depopulation $\cdot$ marginal/problem areas $\cdot$ rural revival - reviving village $\bullet$ methodology for rural studies - Sudetes Mountains

\section{Introduction}

The rural areas worldwide have been subject to very intense and multidirectional transformations in the recent decades, which affect their socio-economic and functional, as well as spatial structures. These phenomena can be linked to the processes, such as urbanization (Batzing et al., 1996) or globalization, including among other the global market and the world funding programs (EU funding schemes, World Bank), etc. (Amin, 2002; Woods, 2007, 2013; Kairyte, 2015). The diversity and complexity of sitespecific factors, such as social and territorial capital, are able to modify the local responses 
to global processes and they contribute to the progressing polarization of rural areas (e.g. Rosner, 2012; Sánchez-Zamora, et al., 2014, Wesołowska, 2018a). As a result, a fast development of rural areas in some regions is counteracted by a decline of other areas; this can be described as polarization of the current socio-economic processes in rural areas (i.e. Li et al., 2019). A particularly high pace of recent transformations could be observed in rural areas in the countries of Central and Eastern Europe since their political and socio-economic transitions in the late 1980s (Kučera \& Chromý, 2012; Bezák \& Mitchley, 2014; Kupková \& Bičík, 2016; Skokanová et al., 2016).

The decline of rural areas can be interpreted in a broader context of marginalisation and peripheralisation. Although these negative processes can affect both urban and rural areas, in the latter ones they are usually more pronounced due to their traditional monofunction and limited availability of other economic opportunities in comparison to urban areas. Both marginalisation and peripheralisation are highly complex phenomena, which have been discussed and defined in many different ways. Marginalization is usually linked with the lack of diverse aspects, such as lack of: resources, access, relation, cultural integration, adaptation etc., which can lead to underdevelopment and economic, social, political and/or cultural disadvantages (Leimgruber, 2004; Bernt \& Colini, 2013; Pelc, 2017). Peripheries refer to the well-established concept of the centre-periphery (Wight, 1983), which includes both the physical aspect of accessibility (geographical centre/periphery) as well as economic and social relationships between the core and other areas (Schmidt, 2007; Pénzes, 2013). In this context periphery is not only linked with remoteness of an area but also with its complex socio-economic connections with a centre, and especially with the access to diverse public services (Pezi \& Urso, 2016; Humer, 2018; Salvatore et al., 2018). Such conceptual rather than territorial approach was the base for proposing the concept of inner peripheries (Vaishar, 2006), which broadens the traditional perception of peripheric regions as remote areas (for example borderlands) (Copus, 2001; Crone, 2012). The regions classified as peripheries often witness numerous problems, such as depopulation, ageing, out-migration, weak labour market, out-commuting and weak infrastructure (Humer, 2018). However, peripheries and especially borderlands can also have a great potential as far as their natural resources are concerned (Kučera et al., 2008; Więckowski, 2013), which in turn can contribute to development of tourism in border and transborder areas (Potocki, 2009; Więckowski, 2010, 2018; Vaishar et al., 2013).

Depopulation is especially often mentioned as one of the main components of marginalisation and peripheralisation, and it can be interpreted as both the cause and effect of these negative trends. It is an example of a negative feedback which has already affected many regions worldwide, including Europe (Shrinking regions... 2008). Depopulation is observed both in some urban (mainly post-industrial) and rural areas and for the latter ones the extreme rates of outflow of inhabitants have been noted mainly in the uplands and mountains (André, 1998; MacDonald et al., 2000; Wolski, 2007), semidry areas (i.e. in the Meditteranean - Collantes \& Pinilla, 2011; Di Figlia, 2016), in border regions (Heffner, 2018) and in any areas classified as peripheries, including inner peripheries (Miszczuk \& Wesołowska, 2012; Lang et al., 2015; Eder, 2018; Wesołowska, 2018b). Depopulation is linked both with the unfavorable socio-economic conditions and harsh physical environment, including limited accessibility due to topography and unfavourable conditions for traditional economic activities such as agriculture (climate, soil, slopes) (i.e. Strijker, 2005; Collantes \& Pinilla, 2011; McLeman, 2011).

The occurrence of the above mentioned and highly linked processes may result in classification of some areas as problem regions, which usually refers to rural areas (i.e. Churski, 2010; Eberhardt, 1989; Ciok, 
1991; Bański, 2008). Numerous studies focus on these problematic regions, trying to propose solutions and new development paths for the less privilege rural areas, such as tourism (Gannon, 1994; Boesch et al., 2011), revitalization of abandoned villages (Di Figlia, 2016; Güler, \& Kâhya, 2019), heritage conservation and promotion in depopulated areas (Filipe \& Mascarenhas, 2011), modernization of agriculture and multifunctional rural development (Berkel \& Verburg, 2011; Bogdanov \& Vasiljević, 2011; Pinto-Correia et al., 2016). The most common proposal for rural areas, are the concepts of multifunctional transition of rural areas (Holmes, 2006, 2012), including the development of tourism services (Brown \& Hall, 2000; Jepson \& Sharpley, 2015; Salvatore et al., 2018) and the new rural paradigm (OECD, 2006; Nørgaard, 2011).

Contemporary processes occurring in rural areas in Poland follow the general global trends and they operate in two different directions (Bański \& Stola, 2002; Heffner, 2016, Wesołowska 2018a). On the one hand, many areas are gradually depopulating (Eberhardt, 1989; Wesołowska, 2016, 2018b; Heffner, 2018; Wesołowska \& Flaga, 2018), on the other hand - some other rural areas undergo transformation related to the processes of renewal (e.g. Wilczyński, 2008), revitalization or suburbanization (Bański \& Wesołowska, 2010; Heffner \& Czarnecki, 2011; Kajdanek, 2012; Czarnecki, 2018). Multidirectional character of changes in the rural areas is particularly noticeable in mountain areas, where in many villages the dynamics of depopulation is very high due to difficult farming conditions and to the symptoms of peripheralisation and marginalization in most of their aspects presented above. At the same time, however, these areas are attractive for tourism development which results in construction of the new recreational facilities and infrastructure.

However, it is quite rare that areas which were previously classified as problem regions due to their long-term depopulation and economic recession would show any symptoms of local revival of socio-economic processes.
Such symptoms are especially surprising in villages which were previously considered as vanished or abandoned, which is for example the case of some highly depopulated regions in Portugal (Filipe \& Mascarenhas, 2011), Italy (Di Figlia, 2016) or Turkey (Güler \& Kâhya, 2019), where the previously abandoned villages are currently revitalized mainly for tourism purposes. Such processes were also identified in the Kłodzko region, which is the most depopulated region in the Sudetes Mountains (Miszewska, 1989; Ciok, 1995) and which has been for many years classified as a problem area by various authors (Zagożdżon, 1988; Eberhardt, 1989; Ciok, 1991; Bański, 2008; Konopińska, 2016). The depopulation was one of the main factors contributing to the classification of the area as the problem region, and other criteria included: ageing of population, dilapidation of buildings, pollution of the environment, which was an important problem in the 1980s (Ciok, 1991). In turn, the collapse of industry in many rural areas in the Sudetes in the 1990s triggered a high level of unemployment, which is another factor in classifying an area as a problem region. Currently, however, this is the area where locally many new socio-economic phenomena occur. They include the development of new housing, tourist infrastructure, small entrepreneurship, creation of new rural communities and diverse civic activity including formation of local organizations and associations (local nongovernmental entities). Therefore, the question arises whether current processes taking place in the problem area can be labelled as a revival of villages and whether there is a firm turnabout in the trends of depopulation and economic regression of this marginal region which had been prevailing over the last hundred years? We use the Kłodzko region as a test area to verify if the new phenomena can be interpreted as a revival of villages which can be further adopted to any other marginal/ problem rural areas in other parts of the world.

A term revival was deliberately used here to highlight the difference from the concepts 
of revitalization or village renewal (Wolski, 2017; Sukała \& Dej, 2018). The latter ones are also commonly used in terminology related to the transformation of rural areas but they are difficult to link up to the phenomenon we are dealing with in the study area. There are villages in the Kłodzko region, which have experienced extreme or total depopulation in their post-war history and they have been either completely degraded or have only survived in a vestigial form (Szmytkie, 2008; Latocha, 2013; Latocha, et al., 2018). Meanwhile, the diverse programs aiming at rural renewal, such as "Renewal of the Lower Silesian Village" which comprises also the Kłodzko region, include mainly larger villages, where there is an organized community and a local leader (information from the Marshal's Office of the Lower Silesian Voivodship), hence the depopulated areas remain outside these activities. Revitalization in turn is a strictly formal process according to the legislation act, where it is defined as "the process of bringing degraded areas out of crisis, conducted in a comprehensive manner through integrated actions for the benefit of the local community, space and economy, territorially concentrated, carried out by revitalization stakeholders based on the municipal revitalization program" (Revitalisation Act, 9th October 2015, Dz.U. 2015 poz. 1777). This does not apply either to the depopulated areas where the observed processes of revival are bottom up phenomena and no official revitalization programs have been applied. Therefore, a new terminology should be proposed to grasp the new phenomena in the highly depopulated or even vanished villages which have been recently subject to revival processes.

The commonly used typologies of rural areas in Poland (i.e. Bański \& Stola, 2002; Bański, 2014; Stacherzak \& Hełdak, 2013, 2019; Mazur et al., 2015; Śleszyński \& Komornicki, 2016) cannot accurately picture the latest symptoms of socio-economic revival because these typologies are proposed for larger administrative units (usually communes - gminas). However, the actual changes are usually unevenly distributed within a given gmina, and that is why they are observed only at a local scale (village scale) and not within the gmina (commune) as a whole. Therefore the aims of the paper are as follows: (1) To propose a definition of a reviving village based on the recent studies on the current socio-economic and spatial processes which are observed in the villages in the Kłodzko region. (2) To propose a research procedure for identification of reviving villages. We try to answer the following research questions: what are the symptoms of rural revival in marginal areas? What criteria should be used in order to identify a reviving village? What are the limitations of the proposed methodology? The proposal of the new concept of the reviving village and the tools for its identification is based on both the exiting studies and current authors' research.

The time range of the presented analysis covers the post-World War II period, but in order to present the broader context of the long-term demographic changes in this area, the first part of the research covers the pre-WWII period back to the mid-19th century when population in the region reached its maximum in most of the villages. However, the substantial changes in social and economic tendencies in the study area have been observed only after 1989 , and especially from the 2000s, which is similar for the Central European countries (Kučera \& Chromý, 2012; Bezák \& Mitchley, 2014; Kupková \& Bičík, 2016; Skokanová et al., 2016). This time range is also conditioned by the limited availability of some data from the earlier periods.

\section{Study area}

Kłodzko region is located in the Sudetes Mountains, which form the Polish-Czech border, and covers an area of $1643 \mathrm{~km}^{2}$ with population of 160 thousand (57 thousand in rural areas). Its boundaries follow the administrative borders of the Kłodzko county (poviat). As a border region, it has often changed its nationality, and, as a result, became an area of diverse conflict and intermingling of Polish, German and Czech nations. Due to the 
general shifts of the Polish border westwards after the World War II the original German population was forced to leave and the new settlers arrived, mainly from central and eastern Poland (also from this part of the pre-WWII Poland, which is now Ukraine) (Gawryszewski, 2005; Eberhardt, 2015). This exchange of population has its long-lasting and multifaceted effects until present.

\section{Depopulation}

During the post-WWII period the rural areas of the entire Sudetes Mountains underwent significant processes of depopulation, however they were most visible in the Kłodzko region (Tomaszewski, 1968; Salwicka, 1978; Jerkiewicz et al., 1979; Miszewska, 1979, 1989; E. Kościk, 1990; J. Kościk, 1990; Zagożdżon, 1990; Ciok, 1994, 1995). Partial or total depopulation of many settlements in rural areas has led to the decline of entire villages or parts of them (Chachaj, 1978; Szmytkie, 2008; Latocha, 2013, 2015). The resulting changes in land use led to considerable lowering of the altitude of the agriculture-forest boundary and the dilapidation of buildings in abandoned villages (Plewniak, 1978; Zagożdżon, 1990; Ciok, 1995; Latocha, 2012).

The long-term analysis of population trends, comparing the pre-WWII and postwar period indicate that for most villages (131 out of 174 in the Kłodzko county) the depopulation was 50\% and more, and for over a third - over 80\% (Latocha et al., 2018), including settlements which disappeared completely (Szmytkie, 2008; Latocha, 2013, 2015). In addition, the selective character of post-WWII migration (mainly outflow of young people) caused a transformation of the demographic structures of villages, in particular ageing of the population and lowering the birth rate (Zagożdżon, 1990). As a result, the study area presented all the symptoms typical for marginal and peripheral areas in their broad sense, not only related to its location in the mountainous borderland (Copus, 2001; Vaishar, 2006; Schmidt, 2007; Crone, 2012; Pénzes, 2013; Pezi \& Urso,
2016; Humer, 2018). Therefore the region has for many years been classified as a problem area by different authors and according to various typologies (Zagożdżon, 1988; Ciok, 1991; Bański, 2008; Konopińska, 2016).

\section{Current changes}

\section{Demographic changes}

Although depopulation processes can still be observed in the study area, last 30 years brought some signs of rural revival in some villages, especially those which have traditionally been considered as disappearing (Szmytkie \& Tomczak, 2017). Although data from specific districts is still an accurate illustration of deepening depopulation processes and acute population aging in Kłodzko region (in 2012 the senility index for rural areas in Kłodzko region was 93, while the average value for villages in Poland was 77 - Szmytkie \& Tomczak, 2015), the analysis of changes in population size of specific villages unveils far more complex nature of population dynamics in the region under study.

Between 1988 and 2002 population size increased in 31 villages of Kłodzko region, while a total size of rural population in the poviat went down by $5600(8,7 \%)$. In the period 2002-2011 population size increased by 650 people $(1,1 \%)$, and in 95 villages the number of inhabitants stagnated or went up, as in 49 villages where an increase was of at least $5 \%$. Depopulation process was still taking place, but its scale was significantly diminished. An increase in the size of rural population can be explained by suburbanization and by the influx of new inhabitants into villages which had previously depopulated and were described as vanished or disappearing (Chachaj, 1978). An increase in population of many previously depopulating villages observed between 1988-2011 does not change the quantitative image of the study area, but it does make a significant qualitative change. The difference arises from the fact that new inhabitants come from cities and it results in rejuvenated age structure as well as in positive changes in the structure 
of educational attainment. These processes and their results can be interpreted as the demographic aspect of rural revival.

\section{Economic and functional changes}

The number of business entities registered in the rural areas of Kłodzko region decreased between 2004 and 2016 from 8300 to 7700 (by 8 pp.) The most significant decrease was observed in the agriculture sector (from 4800 to 3900 ; by 19,3 pp). Such decline depicts a gradual transformation in the structure of business entities - from a structure that is typical of agriculture, through agricultureservice and service-agriculture, to a structure that is dominated by services (Sikorski et al., 2020). In that period the number of employees in agriculture went down by 6,3 pp. and simultaneously the number of employees in services went up by 6,2 pp. The most dynamic functional changes took place in villages characterized by the most marked population increase. It can be interpreted as a sign of an increased entrepreneurship in previously depopulating villages and an indication of economic-functional rural revival (Szmytkie \& Tomczak, 2017, 2018).

Tourism is one of the most important drivers of economic development. It has profoundly influenced Kłodzko region. As data shows, the volume of tourist accommodation in the rural areas has increased from 6100 in 1988 to 12,600 in 2012 and 16,700 in 2019. One of the most popular forms of accommodation in villages is staying at small individual accommodation and agritourist farms. According to data collected by the Provincial Agricultural Advisory Centre in Wrocław, there were 198 agritourist farms in Kłodzko region in 2012 (31\% of the total number for the Lower Silesia province). Additionally, every tenth farm was certified as an ecological farm.

\section{Spatial and landscape changes}

Introduction of agri-environmental programmes and other direct payments for areas with unfavourable conditions for agriculture, which became available since 2004 when Poland accessed the EU (Mastalska-Cetera, 2006; Kutkowska, 2014), resulted in a return to farming in many areas which have for years been abandoned. Secondary plant succession has been stopped and these areas became opened areas again, used mainly as hay meadows and pastures. This is the result of preferred types of support that farmers in the Kłodzko region choose, i.e. options which allow for keeping extensive, permanent grasslands (Latocha, 2016). Changes in settlement have also brought a significant landscape transformation. The contemporary share of built-up areas in the Kłodzko region is practically the same as at the end of the 19th century (about 5\%) (Latocha et al., 2016), but there were significant changes in their spatial distribution. Decline of dilapidated, abandoned housing (visible in the form of numerous ruins), has been topped up with new housing located in more accessible and more attractive spots. In the post-war period, until the mid1990s, the number of new housing was relatively low. In some villages there were no new investments. Since the end of the 1990s, and especially at the beginning of the 21st century, there has been far more construction activity (Latocha, 2017). Development of new housing in the rural areas in the vicinity of towns and cities - the process of suburbanization - resulted in many spatial as well as societal transformations (Kajdanek, 2009, 2011). An important qualitative change in the landscape results from renovations and reconstructions of many pre-war houses and farm buildings. Refitting of these buildings is usually done with understanding and respect for the traditional regional architecture. The processes presented above can be described as spatial rural revival (Latocha, 2013, 2017).

\section{Societal changes}

Non-governmental organizations are considered an important element of civic society, an indicator of the level of social capital, civic engagement and agency (BednarekSzczepańska, 2011). Studying NGOs allows 
to determine the direction and scale of social changes in a particular region. Kłodzko region is unique nation-wide in the aspect of a dynamic increase of registered NGOs and in the structure of their activities (Sikorski 2020). Between 2000 and 2017 the number of $\mathrm{NGOs}$ registered in Kłodzko region increased from 268 to 749 . There was an annual increase in the number of NGOs of $15,5 \%$ while nation-wide average was $2-3 \%$. Moreover, the increase in the number of NGOs in the rural areas of Kłodzko region was even higher - $18 \%$ annually.

A social transformation of Kłodzko region is reflected in the structure of activities taken up by the local NGOs. The most popular activities nation-wide are these related to sports, tourism, leisure $(29,1 \%)$, protecting health and increasing security $(16,5 \%)$, protecting cultural heritage (11,9\%) (GUS 2018). However, in Kłodzko region the most popular activities are related to culture and arts $(18,3 \%)$, local development (17,8\%), supporting employee affairs (trade unions) (14,4\%). Every fourth NGO in Kłodzko region is focused on art and culture and local development, and especially on supporting specific villages (Sikorski, 2020). These tendencies can be an example of societal aspects of rural revival.

\section{The theoretical and methodological frames}

\section{The concept of the reviving village}

The current transformations of the investigated problem region, which were presented above, show that there are new local development trends in former depopulation areas. These observations have become an inspiration to our attempt to identify the new processes in a more comprehensive way. As a result, a new category of "reviving village" has been proposed. It can be defined as a village, which - after many years of depopulation and recession leading to a significant or even complete decline - has recently experienced some symptoms of revival, including its diverse aspects: demographic, economic, functional, social and spatial/landscape. To classify a village as reviving, we propose the assumptions that the initial depopulation should be at least at the level of $50 \%$ (comparing the maximum and minimum number of inhabitants in the investigated period from mid-19th century until present), the village should be small (less than 250 inhabitants) and it should have at least 3 out of 5 identified symptoms of revival. The exact procedure of identification of reviving villages is described in details in the next part of the paper, along with the explanations of the rationales for the presented assumptions, which - in turn - can be modified in other areas and adopted to the local constraints specific for a given region or country. What is also important, the reviving processes are usually spontaneous, bottom-up phenomena and in most cases they are not part of an organized, top-down programs or large projects, such as revitalization or renewal, which was discussed above.

\section{How to identify a reviving village?}

Identification of the reviving villages - research procedure

The procedure we propose to identify the reviving villages includes three main stages: (1) initial selection of the most depopulated villages, (2) theoretical designation of the reviving villages based on the secondary data analysis of statistical data from various databases, (3) collection of primary data (quantitative and qualitative) during field research in order to validate the theoretical assumptions (Fig. 1).

\section{Initial selection of the most depopulated villages}

The revival is possible only if the decline and depopulation were observed in the previous period. Therefore, in the first stage of our research the villages with the highest degree of depopulation were selected. Calculations were made by comparing the maximum number of the population in the pre-World War II period, based on censuses starting from mid-19th century, with the minimum 




Figure 1. Identification of the reviving villages - research procedure

number of the population in post-war times. As a result we obtained a measure of maximum depopulation level for each village in the period of 135 years. To assure the consistency of data only census data were used (1867, 1875, 1885, 1895, 1905, 1925, 1933, 1939 and 1950, 1960, 1970, 1978, 1988, 2002). The selection of the mid-19 $9^{\text {th }}$ century as the starting point for the demographic analysis is justified by the fact, that most villages in the study area reached the maximum population in their historic development in the second half of the 19th century and we wanted to capture the maximum depopulation, which was experienced by each village.

Taking into account the level of depopulation (expressed in \%) we designated villages which can be labelled as depopulated. Two criteria were used to do that: level of depopulation and the current size of a village. Using the statistical method of natural breaks we defined two compartments of approximately 79\% and 50\% level of depopulation. It was decided that for further analysis we would use a set of localities which experienced depopulation of at least 50\% (between pre-World War II and post-WWII period) in order to analyse a larger set of villages and thus to better capture all their new paths of development. Simultaneously, we selected the villages which are considered as small ones, with current population not larger than 250 inhabitants, to verify if the smallest settlements were also able to return to the development paths although their socio-economic capital is very low due to their small size. We choose the interval of 250 inhabitants as this was the average size of a village in Poland in the 1990s, which is the starting period for the transformation 
of the rural areas which are discussed in this paper. Each village classified to the next stage of research needed to fulfil both criteria. In total, 103 villages (out of 174) were classified to the second stage of research, including 7 villages which were completely abandoned.

\section{Theoretical designation} of the reviving villages

The process of rural revival may become apparent in varied ways as it was presented above. Therefore in the next stage of the research we set up five criteria which allow for identification of depopulated localities which have recently experienced some processes of the socio-economic revival. They include: (1) Demographic changes - quantitative and qualitative characteristics of the current demographic trends, (2) Functional changes - analysis of the economic base and main sources of income for village populations, (3) Economic changes and specifically changes in tourism infrastructure - number of facilities and accommodation in different time range, (4) Spatial and landscape changes - new developments, technical infrastructure, renovations and changes in land use, (5) Social changes - analysis of activities in local communities based on NGOs.

At this stage of research it was assumed that any increase of a chosen indicator (more people, more economic entities, more tourist facilities, more new houses, more NGOs) between the initial year of observation and

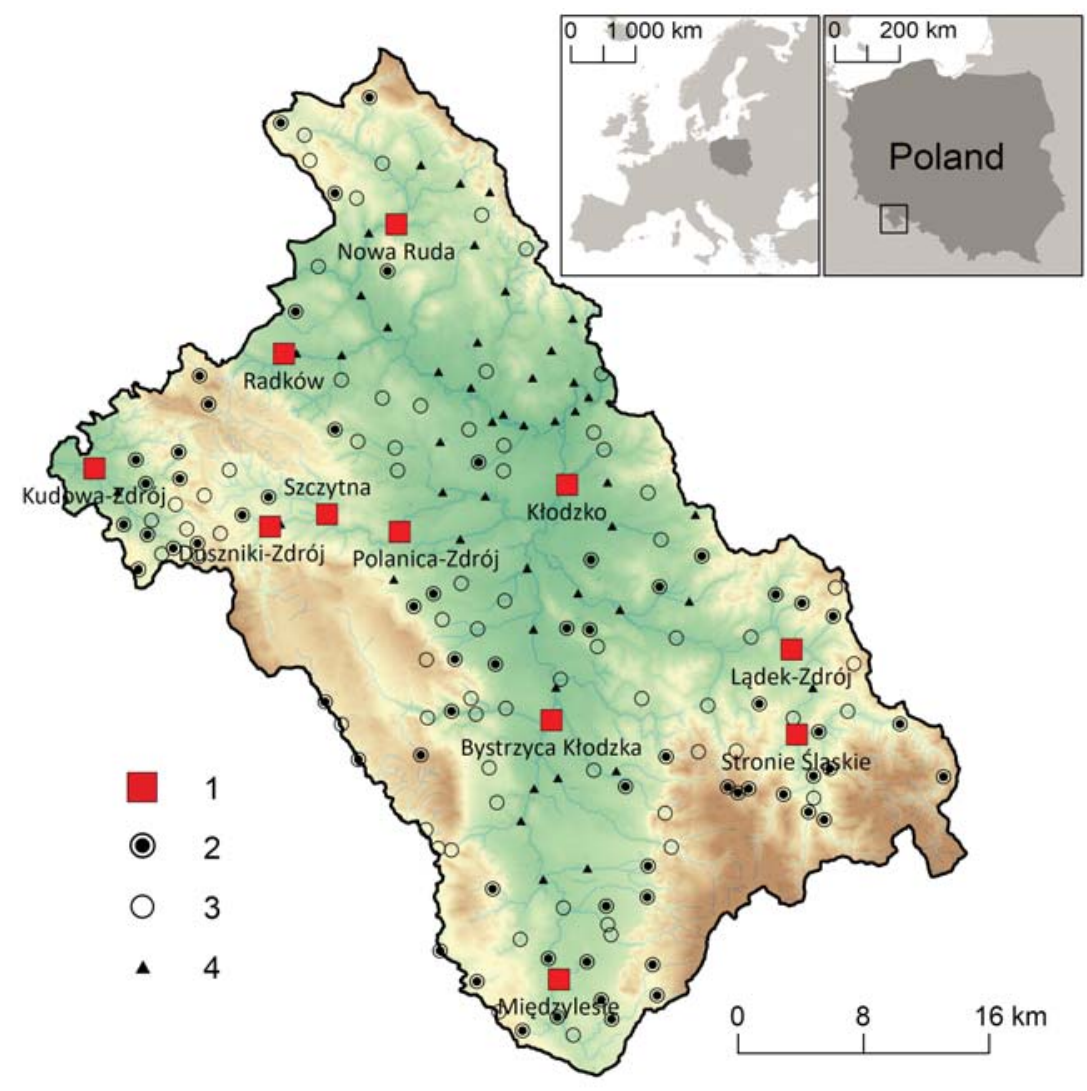

Figure 2. Study area with various categories of villages. Legend: 1 - towns, 2 - villages with symptoms of revival (explanations in the text), 3 - villages depopulated $50 \%$ and more in the period between mid-19th and present, 4 - other villages 
present, regardless its value, signals the process of revival (zero-one system). This assumption can be justified as follows. First, it is related to the fact that the entire test area (Kłodzko region) has long been considered a problem area and in the 1980-1990s it was characterized by a general tendency of degradation and decline of almost all socio-economic indicators. Any increase should be considered at this point as a sign of a positive change (revival) of such an area. Secondly, the scale of changes was often very small in absolute numbers but large at the same time in relative terms - due to the small size of the locality. Setting quantitative (numerical) criteria will not work in such a case.

Each criterion was based on the various available data sources which are presented in details and critically assessed in the next section of the paper. Although the time compartments for particular data bases are different, they include in general the turn of the 20th and 21st century or the beginning of the 21 st century, when the processes of revival became particularly visible. Decision on how to set up the lower and the upper bracket for a time range in case of each indicator was determined by data availability (as described below).

In the next step we juxtaposed data referring to five selected criteria and made a ranking. The following field visits were conducted in 64 villages (with depopulation level of 50\% and more, and smaller than 250 inhabitants) which have fulfilled at least 3 criteria of revival (Fig. 2).

\section{Field visits}

Statistical data collected for all 64 villages were verified during field visits which included taking an inventory of all business entities, farms, tourist facilities and quality of housing developments. In each village we have also conducted exploratory interviews with informed inhabitants in order to get the best possible overview of each village. During field visits we used a structured observation protocol for each village, which was our own invention. It consisted of sections on: (1) housing and development - number of houses in total, number of newly constructed houses, temporary/permanent occupation, origin of investors (locals or newcomers), location of new development in regard of the core of the village, renovations of old buildings, ruins and abandoned houses; (2) inhabitants - number of inhabitants, age, number of children, including school-aged children, division of inhabitants into locals and newcomers, origin of newcomers, temporary/permanent living in the village, general opinion on relations between locals and newcomers, general opinion on everyday life in the village; (3) economy - sources of income, business entities in the village (verification of the Register of National Economy); (4) landscape interventions and care of the surrounding (e.g. cutting trees, fallow land, thick bushes, mowing, aesthetics of courtyards); (5) tourist development - accommodation, gastronomy, ski lifts, tourist paths, tourist attractions (including cultural heritage sites); (6) technical and service infrastructure - category and quality of roads, water and sewage infrastructure, shops etc.; (7) transportation - public transportation to and from a village, train stations and bus stops, frequency of connections, people's needs regarding public transportation; (8) social infrastructure and social activities playgrounds, sport facilities, meeting places, active associations - who belongs to them, what they do, who is particularly active.

Apart from the highly structured features mentioned above, we have also taken notes reflecting our subjective views regarding the process of revival (or stagnation and degradation) in the villages we visited. It was a valuable addition to statistical data, field structured data and exploratory interviews.

In addition, in order to further verify the revival process, a dedicated website was created with an interactive map of the studied villages (www.odrodzenie-wsi.pl). It should not only be a knowledge platform, but also a platform for the exchange of ideas and remarks between scientists and the society, especially the local communities. The possibility to write comments by all the readers of the website 
brings the opportunity to get a better insight and another perception of the phenomenon under study.

The results of the analysis of statistical data and of the field visits allowed to create an extensive database for the villages under study including all elements described above. This database allowed for selecting villages for the next stage of quantitative and qualitative social research which aimed to identify the driving forces and conditions for rural revival. However, this theme goes beyond the scope of the presented article and will be discussed in a separate paper.

\section{Materials and data sources - a critical assessment}

Each criterion was analysed with reference to a different set of data, which we assess critically below. The basic requirement - and difficulty of the method - is the availability of the data at a level of a single village and not larger administrative units such as gminas (communes). The sources of data for each criterion of revival are presented in Table.

\section{Sources of data:}

The information about demographic data can be based on two different sources of information: national censuses and official database on population registration (PESEL) (Tab.). However, differences in methodological approach to data collection in 2002 and 2011 census and PESEL database make it impossible for a systematic comparison in different time ranges. It is only achievable to describe more general trends or discuss sets of data separately. Additional methodological problem is connected with an apparent disparity between the number of inhabitants registered for the census and the actual number

Table. Criteria used for classification of rural revival with their data sources and timeframes

\begin{tabular}{|c|c|}
\hline Criteria for village's revival & Sources of data and timeframes \\
\hline $\begin{array}{l}\text { Demographic changes - quantitative and qualitative } \\
\text { characteristics of the current demographic trends }\end{array}$ & $\begin{array}{l}\text { National Census 1988, 2002, 2011; PESEL' database } \\
\text { 2000-2016. }\end{array}$ \\
\hline $\begin{array}{l}\text { Functional changes - analysis of the economic base } \\
\text { and main sources of income for village populations }\end{array}$ & $\begin{array}{l}\text { Register of National Economy (REGON) })^{2} \text { database (1998- } \\
\text { 2018); Central Registration and Information on Business. }\end{array}$ \\
\hline $\begin{array}{l}\text { Economic changes and specifically changes in tourism } \\
\text { infrastructure - number of facilities and accommodation } \\
\text { in different time range }\end{array}$ & $\begin{array}{l}\text { Publication "Equipping villages and towns with basic } \\
\text { facilities and equipment in the Wałbrzych voivode- } \\
\text { ship" (Wyposażenie miast i miejscowości wiejskich } \\
\text { w podstawowe placówki i urzadzenia w województwie } \\
\text { wałbrzyskim) (1988); data scraping from websites and } \\
\text { internet browsers for accommodation in Kłodzko county } \\
\text { (2013 and 2019). }\end{array}$ \\
\hline $\begin{array}{l}\text { Spatial and landscape changes - new developments, } \\
\text { technical infrastructure, renovations and changes } \\
\text { in land use }\end{array}$ & $\begin{array}{l}\text { Individual building permits from the Kłodzko County Of- } \\
\text { fice (annual data from 1999) and from municipal (gmina) } \\
\text { offices (for some districts data available from } 1975 \\
\text { to 1998); cartographic materials (including The National } \\
\text { Database of Topographic Objects BDOT10k); orthophoto } \\
\text { maps and aerial photos from various periods (1970s, } \\
\text { 1990s, and current); statistic data on types of land } \\
\text { use, including the information on agri-environmental } \\
\text { schemes available from the Agriculture Restructuring } \\
\text { and Modernization Agency; field visits. }\end{array}$ \\
\hline $\begin{array}{l}\text { Societal changes - analysis of activities } \\
\text { in local communities based on NGOs }\end{array}$ & National Business Registry (1998-2018) for NGOs \\
\hline
\end{tabular}

1 Universal Electronic System of Population Registration (PESEL) - a central data collection kept in Poland by the minister responsible for computerization under the Act on population registration

2 REGON - Register of National Economy - register kept by the President of the Central Statistical Office. 
of inhabitants. The gap results from no legal obligation for the people to officially change the dwelling address when they move. As a result, what is being counted in censuses are people registered in specific localities and not people who actually live there (Śleszyński, 2011; Gołata, 2012).

The functional changes are considered as the changes in the economic base and in the main sources of income for village population. Such data can be obtained from the official Register of National Economy (REGON) (Tab.). However, there are several problems concerning National Business Registry database which were also signaled by other researchers (i.e. Śleszyński, 2007; Ilnicki, 2009; Raczyk, 2009; Celińska-Janowicz, 2016; Kłosowski, 2017): (1) there were four different classifications used in Polish Classification of Economic Activities (PCEA) in the analyzed time range (1997, 2004, 2007, 2010); (2) REGON database was introduced in 1995 but it was not a complete set of data; from time to time new types of activities were added, e.g. in 2000 National Business Registry database did not register farms - they were introduced in 2004; (3) small businesses, usually run by self-employed people, are registered in the person's place of dwelling and not in the place where the economic activity is actually undertaken; (4) in case of shutdown, business entities do not inform about it; (5) it is a common practice - not always justified - to register a very broad scope of economic activity which covers even up to several dozens of PCEA groupings, while in fact, the business entity only operates in some of them; (6) there is no single methodology to catalogue economic activity for the transition period from 2004 to 2007 - there is only a translation key facilitated by the Statistics Poland. The key is controversial because it does not offer a full transition for every type of economic activity (e.g. for individual proprietorship businesses) and also classifies one type of activity from 2004 under many different types of activities in 2007 (e.g. 20.52.Z $\rightarrow$ 16.29.Z and 32.99.Z); (7) because of the transition from PCEA 2004 to PCEA 2007 individual proprietorship businesses had to be manually ascribed to a relevant section; (8) incoherence of definitions and names used in the following years, especially in case of a decentralized CRIB database; (9) some categories of services and retail are not counted in the database (e.g. bank agencies); (10) legal changes regarding establishment and registration of business entities, for example the recently introduced lack of obligation to register business operations according to Business Law Act introduced on April 30th 2018 (Art. 5 paragraph 1 of the Business Law Act).

The analysis of changes in tourism infrastructure (which is regarded as the main economic change in the study area), which included the comparison of number of facilities and accommodation in different time ranges, were very difficult to perform. Due to disparities between data sets from various data bases (e.g. Local Data Bank, The Institute of Tourism, data from local authorities), and credibility deficiency regarding data for statistical territorial units, it is necessary to use other sources of data in order to assess the actual volume and distribution of tourist accommodation. Useful sources of data are tourism-oriented search engines and websites of local administration. Additionally, a lot of information can be gained from field visits. Data obtained from Statistics Poland only shows collective accommodation facilities and overlooks individual accommodation facilities (guest rooms, agritourist farms) (Szmytkie, 2015).

The spatial and landscape changes in the villages were based on various types of sources (Tab.), but there are limitations in some of them as presented below. Individual building permit data are burdened with the following problems: (1) data collection is incoherent - local districts had collected and archived data until 1998 individually without one, consistent methodology (it is not unusual to find hand-written data); in some local districts older data is not available; (2) since 1999 individual building permits are issued by the County Office but archives are not consistent hence the quantity and quality of data for different 
time range is extremely varied; (3) the number of the building permits issued is usually lower than the number of houses actually built due to the lack of notification of construction completion. Therefore field visits and analysis of cartographic materials (i.e. The National Database of Topographic Objects BDOT10k, aerial photos and orthophoto maps) are necessary. Moreover, the renovation of old housing is the most difficult aspect to grasp. Refurbishment significantly changes the aesthetic appearance of rural areas, but it can only be identified during field investigations.

The main problem with the analysis of NGO units (which are an important indicators for societal changes - Tab.) based on National Business Registry is the definition of a NGO and classification of a business entity as NGO. In the relevant literature there are various classifications of NGOs. For the purpose of this research the broadest definition was adapted, proposed by portal. ngo.pl. This definition is similar to the legal definition (Art. 3 paragraph 2 of the Public benefit and voluntary organisation Act from April 24th, 2003; Journal of Laws of the Republic of Poland from 2018, position 450). Another problematic piece of information is on the location of the NGO which does not always correspond with the actual area of activity. Moreover, not all social initiatives undertaken in rural areas are formalised by registration at National Court Register, Polish Classification of Economic Activities, etc. As a result they are not included in the official databases, not even in National Business Registry. Another difficulty is caused by the changing vocabulary which reflects various concepts and socio-political as well as theoretical contexts for the functioning of NGOs in Poland (Gliński 2004), and particularly in rural areas (Herbst, 2018).

\section{Applicability and limitations - discussion}

The analysis of the current socio-economic and spatial processes which are observed in the study area suggests that some villages
- after years of stagnation or decline - have recently returned into the development path, as defined in Li et al. (2019). The field surveys confirmed that the phenomena identified on the basis of initial statistical analysis have also their expression in real physical and socioeconomic space of the analyzed villages.

Due to the discussed methodological problems with data sources, and especially the large diversity of available databases, including their spatial and temporal inconsistency, as well as different methodologies for collecting the same information in different periods, preparation of the input materials for the presented analyzes required a lot of work to adapt them for comparative studies. However, despite the discussed imperfection of the source materials and the need to make certain assumptions, simplifications or generalizations of data in order to make any comparative analyzes for different years and different sets of data possible, these are the only official statistical data that are available at all. Hence, we use them with full awareness that they should be treated as some kind of estimates and approximations of the observed trends, and not as the absolute data. Regarding this limitations of the statistical sources, the field surveys were the key aspect of our research on identification of the reviving villages. The direct observations and interviews with local inhabitants were valuable sources of information supplementing quantitative data obtained from official public databases, and verifying them at the same time, which was necessary given their often inconsistent and problematic nature as discussed above. Field surveys also allowed to capture phenomena that are not noticeable using statistical data (e.g. bonds between residents, level of life satisfaction etc.). They were also crucial for identifying the high spatial diversity in predominance of individual symptoms of revival, or their specific sets - the statistical data was not sufficient to clearly define the actual importance of each of the criteria. Field visits are actually necessary wherever data are aggregated at a level equal to and higher than the commune given the very local and 
site-specific character of revival processes. These are important observations for further research with focus on the identification of the factors supporting or restraining the revival processes.

As a result, the combined statistical and field data confirmed that the general trends observed in the study area are strong enough to interpret the recent, multifaceted developments of some villages in the Kłodzko region as rural revival. The proposed methodology for identification of reviving villages should be thus considered as positively tested. Nevertheless, the criteria for identifying the processes of rural revival can vary spatially in different areas and countries, and should be adopted to the regional needs. They depend both on the specific characteristics of the analyzed areas and on the available data, which is varied in different regions and countries. Additionally, the selected criteria should be related to the specific aspects of marginality and peripherality which are present in a given problem area as well as to the initial identification of the main symptoms of these negative trends - are the disadvantages, shortages, and inconveniences related rather to the physical or socio-economic, or demographic or political context? (Copus, 2001; Leimgruber, 2004; Vaishar, 2006; Schmidt, 2007; Crone, 2012; Bernt \& Colini, 2013; Pénzes, 2013; Pezi \& Urso, 2016; Pelc, 2017; Humer, 2018). Regardless the possible diversity of the applied criteria of revival, the proposed steps in the identification procedure of reviving villages seem to have the potential to be applied in diverse places and the methodology can be adopted to other problem and depopulating areas.

Therefore, we hope that the results of our study might be an important contribution to the debate on the ways to support the problem regions and on various attempts to counteract their marginalization and peripheralization (Gannon, 1994; Romano, 1995; Leimgruber, 2004; Berkel \& Verburg, 2011; Bogdanov \& Vasiljević, 2011; Pinto-Correia et al., 2016; Boesch et al., 2011; Serra et al., 2014; Pelc, 2017). The results prove that the symptoms of socio-economic, functional, demographic and spatial revival are possible to occur even in the regions for a long time considered problematic. They also show that even the long-lasting negative trends can be locally overcome and reversed. Even the villages with the least favorable conditions for development (highly depopulated and small) might return to the development path, which also gives hope to other disadvantageous rural areas (Li et al., 2019).

It should be especially highlighted that the observed new trends in most cases represent a bottom-up approach, where some individual decisions contribute to the general improvement of the living conditions and better perception of previously declining villages. Most of the revival processes observed in the study area were not related to any special external programs such as revitalization or renewal. This observation might be important in the discussion on the solutions for problem and declining rural areas as the new trends identified in the study area are in line with the general concepts for development of rural areas, such as the new rural paradigm and multifunctional transition, and especially the growing importance of tourism (OECD, 2006; Brown \& Hall, 2000; Nørgaard, 2011; Holmes, 2012; Jepson \& Sharpley, 2015; Salvatore et al., 2018). Thus the proposal of a new concept of a reviving village, its definition, as well as the development of a new methodology for identification of villages, which can be considered as reviving, might be a useful tool for studying the current transformations of marginal rural areas also in other regions worldwide. Although the methodology has some weaknesses and imperfections, mainly due to the problematic source materials, the application of diverse research approaches and different data sources allows to validate and verify the obtained results from various perspectives and using the complementary methodologies of both human geography, carthography and landscape studies, as well as social sciences.

The concept of the rural revival represents a pioneering research as the phenomenon 
of the socio-economic revival of villages observed after many years of their nonexistence or stagnation in the residual form is a new process in the Polish space, hence not yet analyzed in the literature on the subject. Also in the world literature the research carried out in the depopulated areas focused mainly on the causes and spatial diversity of depopulation, or their socio-economic, environmental and landscape consequences, or both (i.e. Strijker, 2005; Collantes \& Pinilla, 2011; McLeman, 2011; Bezák \& Mitchley, 2014; Plieninger et al., 2016). Although there are papers presenting various ways how to revitalize or re-use the abandoned villages (Filipe \& Mascarenhas, 2011; Di Figlia, 2016; Güler \& Kâhya, 2019), no comprehensive research has been yet undertaken to analyze the phenomenon of the revival of villages in the multi-aspect dimension, and to present the definition or methodological aspects how to define a reviving village.

The recently increased internal differentiation of development and decline processes in rural areas, even in the adjacent areas within the same region, was noted by many authors (Berkel \& Verburg, 2011; McLeman, 2011; Bezák \& Mitchley, 2014; Bański \& Mazur, 2016; Kerckhof et al., 2016). It is also proved by the observation of the revival processes in the study area, which is spatially highly diverse. A very individual path of development of each village in rural problem areas suggests a need for more sitespecific research, which are scarce at the moment (Bański, 2016; Sørensen, 2018), and especially in the marginal areas. The analysis of the current transformations at the local (village) level and the new classification of the marginal rural areas, including the category of a reviving village, would allow for better understanding of these processes. Moreover, it can also be a useful tool in decision making and planning policy of rural areas, which can help to better meet the local needs through site-specific policies (Strijker, 2005; van Eupen et al., 2012; Almeida et al., 2016; Śleszyński \& Komornicki, 2016; Sørensen, 2018; Li et al., 2019).

\section{Conclusions}

The proposed new category of a reviving village and the research procedure of its identification might be useful in analyzes of the current transformations of the marginal areas. They also respond to the postulates of many authors who call for in-depth research on revitalization, renewal and revival of rural areas (Allison \& Hobbs, 2004; Gleeson, 2008; Larsen \& Barker-Reid, 2009; Li et al., 2019). We pointed out both to the symptoms and criteria for rural revival, as well as to the limitations of the proposed research procedure. This can be useful for understanding new phenomena in depopulating areas and to better distinguish the villages which are currently in the transition period. Especially, that the proposed methodology allows to capture even the slightest symptoms of positive changes in areas considered as marginal and peripheric. It could be the base for creating a typology of the directions and types of rural revival, as well as the classification and hierarchy of factors supporting or inhibiting the revival. The recognition of the diverse driving forces of rural transformations should allow to create a conceptual model of socio-economic development of reviving villages, as well as to forecast the development of socio-economic and spatial processes in the marginal areas. In this context, the concept of reviving villages might be a valuable contribution in a discussion on both endogenous and exogenous factors which currently shape the rural areas worldwide, such as suburbanization, diverse funding programs, local policies for spatial development, the global market, as well as site-specific conditions, and especially the local social and territorial capital, that heavily influence the actual course and scale of the global changes (Greffe, 1994; Courtney \& Moseley, 2008; Berkel \& Verburg, 2011; Ventura-Lucas et al., 2011; Eliasson et al., 2013; Sánchez-Zamora et al., 2014).

The analyses based on the identified reviving villages may also help to address the question of the permanence of the currently observed 
trends of changes. It is important in the context of indicating the factors responsible for the sustainable revival of villages and the sustainability of its effects. This is a key part of the rural resilience, understood as "the capacity for renewal, re-organization and development" (Folke, 2006), which seams appropriate to adapt to marginal and depopulating regions to assess their current transformations.

\section{Acknowledgement}

The research was financed by the National Science Centre in Poland by project no. 2017/27/B/HS4/01220.
The authors are grateful to the Editor and the anonymous reviewers for their valuable comments and constructive criticism.

Editors' note:

Unless otherwise stated, the sources of tables and figures are the authors', on the basis of their own research.

\section{References}

Allison, H.E., Hobbs, R.J. (2004). Resilience, adaptive capacity, and the "Lock-in Trap" of the Western Australian agricultural region. Ecology and Society, 9(1), 3. https://dx.doi.org/10.5751/ES-00641-090103

Almeida, M., Loupa-Ramosb, I., Menezesa, H., Carvalho-Ribeiroa, S., Guiomara, N., Pinto-Correia, T. (2016). Urban population looking for rural landscapes: Different appreciation patterns identified in Southern Europe. Land Use Policy, 53, 44-55. https://doi.org/10.1016/j.landusepol.2015.09.025

Amin, A. (2002). Spatialities of globalisation. Environment and Planning A, 34(3), 385-400. https://doi.org/10.1068/a3439

André, M.F. (1998). Depopulation, land-use change and landscape transformation in the French Massif Central. Ambio, 27(4), 351-353.

Bański, J. (2008). Wiejskie obszary problemów demograficznych. In A. Harasim (Ed.), Wybrane zagadnienia systemów informacji przestrzennej i obszarów problemowych rolnictwa w Polsce (pp. 93-102). Puławy: Instytut Uprawy Nawożenia i Gleboznawstwa - Państwowy Instytut Badawczy.

Bański, J. (2014). Współczesne typologie obszarów wiejskich w Polsce - przegląd podejść metodologicznych. Przeglad Geograficzny, 86(4), 441-470. http://dx.doi.org/10.7163/PrzG.2014.4.1

Bański, J. (2016). Identyfikacja i wykorzystanie zasobów lokalnych w budowaniu przewagi konkurencyjnej - przykład regionu lubelskiego. Studia Obszarów Wiejskich, 44, 7-19. http://dx.doi.org/10.7163/SOW.44.1

Bański, J., Mazur, M. (2016). Classification of rural areas in Poland as an instrument of territorial policy. Land Use Policy, 54, 1-17. http://dx.doi.org/10.1016/j.landusepol.2016.02.005

Bański, J., Stola, W. (2002). Przemiany struktury przestrzennej i funkcjonalnej obszarów wiejskich w Polsce. Studia Obszarów Wiejskich, 3. Warszawa: Instytut Geografii i Przestrzennego Zagospodarowania im. Stanisława Leszczyckiego PAN.

Bański, J., Wesołowska, M. (2010). Transformations in housing construction in rural areas of Poland's Lublin region - Influence on the spatial settlement structure and landscape aesthetics. Landscape and Urban Planning, 94(2), 116-126. http://dx.doi.org/10.1016/j.landurbplan.2009.08.005 
Batzing, W., Perlik, M., Dekleva, M. (1996). Urbanization and depopulation in the Alps. Mountain Research and Development, 16(4), 335-350. http://dx.doi.org/10.2307/3673985

Bednarek-Szczepańska, M. (2011). Organizacje pozarzadowe na obszarach pozametropolitalnych na przykładzie wybranych regionów. Studia Obszarów Wiejskich, 36, 217-231.

Berkel van, D.B., Verburg, P.H. (2011). Sensitising rural policy: assessing spatial variation in rural development options for Europe. Land Use Policy, 28(3), 447-459.

http://dx.doi.org/10.1016/j.landusepol.2010.09.002

Bernt, M., Colini, L. (2013). Exclusion, marginalization and peripheralization. Conceptual concerns in the study of urban inequalities. Working Paper, 49. Erkner: Leibniz Institute for Regional Development and Structural Planning.

Bezák, P., Mitchley, J. (2014). Drivers of change in mountain farming in Slovakia: From socialist collectivisation to the Common Agricultural Policy. Regional Environmental Change, 14, 1343-1356. http://dx.doi.org/10.1007/s10113-013-0580-x

Boesch, M., Renner, E., Siegrist, D. (2011). Strategies for preventing the decline of peripheral areas. Journal of Alpine Research / Revue de géographie alpine, 99-1. https://doi.org/10.4000/rga.1386

Bogdanov, N., Vasiljevic, Z. (2011). Role of agriculture and multifunctional rural development in Serbia. Applied Studies in Agribusiness and Commerce, 5(1-2), 47-55. https://doi.org/10.22004/ag.econ.104642

Brown, F., Hall, D. (2000). Tourism in peripheral areas: Case studies. Clevedon: Channel View. https://doi.org/10.21832/9781873150740

Celińska-Janowicz, D. (2016). Rejestry podmiotów jako źródła danych w analizach lokalizacji działalności gospodarczej w mikroskali. Wiadomości statystyczne, 61(1), 27-43.

Chachaj, J. (1978). Problem wsi zanikajaccej. Acta Universitatis Wratislaviensis, 324, Prace Instytutu Geograficznego, seria B, 2, 119-123.

Churski, P. (2010). Problem areas in Polish regional policy. Moravian Geographical Reports, 18(2), 23-35.

Ciok, S. (1991). Sudety: Obszar problemowy. Acta Universitatis Wratislaviensis, 1236, Studia Geograficzne, 51. Wrocław: Wydawnictwo Uniwersytetu Wrocławskiego.

Ciok, S. (1994). Rozwój osadnictwa na Dolnym Śląsku po II wojnie światowej. Tendencje i kierunki zmian. Acta Universitatis Wratislaviensis, 1591, Studia Geograficzne, 61, 9-49.

Ciok, S. (1995). Zmiany ludnościowe i osadnicze w Sudetach. Acta Universitatis Wratislaviensis, 1730, Prace Instytutu Geograficznego, seria B, 12, 51-64.

Collantes, F., Pinilla, V. (2011). Peaceful surrender: the depopulation of rural Spain in the twentieth century. Newcastle upon Tyne: Cambridge Scholars Publishing. https://doi.org/10.1002/psp.1745

Copus, A.K. (2001). From core-periphery to polycentric development: concepts of spatial and aspatial peripherality. European Planning Studies, 9(4), 539-552. https://doi.org/10.1080/713666491

Courtney, P., Moseley, M. (2008). Determinants of local economic performance: Experience from rural England. Local Economy, 23(4), 305-318. https://doi.org/10.1080/02690940802408029

Crone, M. (2012). Re-thinking "peripherality" in the context of a knowledge-intensive, service-dominated. In M. Danson, P.D. Souza (Eds.), Regional development in Northern Europe. Peripherality, marginality and border issues (pp.67-82). London: Routledge. https://doi.org/10.4324/9780203127247-10

Czarnecki, A. (2018). Going local? Linking and integrating second-home owners with the community's economy: A comparative study between Finnish and Polish second-home owners. Frankfurt am Main: Peter Lang Publishing. https://doi.org/10.3726/b11463

Di Figlia, L. (2016). Turnaround: abandoned villages, from discarded elements of modern Italian society to possible resources. International Planning Studies, 21(3), 278-297.

https://doi.org/10.1080/13563475.2016.1186530

Eberhardt, P. (1989). Regiony wyludniajace się w Polsce. Prace Geograficzne, 148. Warszawa: Instytut Geografii i Przestrzennego Zagospodarowania im. Stanisława Leszczyckiego PAN. 
Eberhardt, P. (2015). Ethnic groups and population changes in twentieth century Eastern Europe: History, data and analysis. London - New York: Routledge.

Eder, J. (2018). Peripheralization and knowledge bases in Austria: Towards a new regional typology. European Planning Studies, 27(1), 42-67. https://doi.org/10.1080/09654313.2018.1541966

Eliasson, K., Westlund, H., Fölster, S. (2013). Does social capital contribute to regional economic growth? Swedish experiences. In H. Westlund, K. Kobayashi (Eds.), Social capital and rural development in the knowledge society (pp. 113-126). Cheltenham: Edward Elgar Publishing Limited. https://doi.org/10.4337/9781782540601.00012

Filipe, M., de Mascarenhas, J.M. (2011). Abandoned villages and related geographic and landscape context: guidelines to natural and cultural heritage conservation and multifunctional valorization. European Countryside, 1, 21-45. https://doi.org/10.2478/v10091-011-0002-3

Folke, C. (2006). Resilience: The emergence of a perspective for social-ecological systems analyses. Global Environmental Change, 16(3), 253-267. https://doi.org/10.1016/j.gloenvcha.2006.04.002

Gannon, A. (1994). Rural tourism as a factor in rural community economic development for economies in transition. Journal of sustainable tourism, 2(1-2), 51-60. https://doi.org/10.1080/09669589409510683

Gawryszewski, A. (2005). Ludność Polski w XX wieku. Warszawa: Instytut Geografii i Przestrzennego Zagospodarowania im. Stanisława Leszczyckiego PAN.

Gleeson, B. (2008). Critical commentary. Waking from the dream: An Australian perspective on urban resilience. Urban Studies, 45(13), 2653-2668. https://doi.org/10.1177/0042098008098198

Gliński, P. (2004). Przemiany sektora obywatelskiego po roku 2000 - analiza porównawcza wybranych wyników badań empirycznych. In P. Gliński, B. Lewenstein, A. Siciński (Eds.), Samoorganizacja społeczeństwa polskiego: III sektor i wspólnoty lokalne w jednoczacej się Europie (pp. 57-79). Warszawa: IFiS PAN.

Gołata, E. (2012). Spis ludności i prawda. Studia Demograficzne, 1(161), 23-55. https://doi.org/10.2478/v10274-012-0002-y

Greffe, X. (1994). Is rural tourism a lever for economic and social development? Journal of Sustainable Tourism, 2(1-2), 22-40. https://doi.org/10.1080/09669589409510681

Güler, K., Kâhya, Y. (2019). Developing an approach for conservation of abandoned rural settlements in Turkey. ITU A/Z Journal of the Faculty of Architecture, 16(1), 97-115.

Heffner, K. (2016). Zmiany przestrzenne na obszarach wiejskich w Polsce w okresie transformacji i po wejściu do Unii Europejskiej. In K. Heffner, B. Klemens (Eds.). Obszary wiejskie. Wiejska przestrzeń i ludność. Aktywność społeczna i przedsiębiorczość (pp. 12-27). Komitet Przestrzennego Zagospodarowania Kraju PAN.

Heffner, K. (2018), Rural labour markets and peripherization processes in Poland. In W. Leimgruber, D. Chang Yi (Eds.), Rural areas between regional needs and global challenges. Transformation in rural space (pp. 53-71). Cham: Springer Nature Switzerland AG.

Heffner, K., Czarnecki, A. (Eds.). (2011). Drugie domy w rozwoju obszarów wiejskich. Warszawa: Instytut Rozwoju Wsi i Rolnictwa Polskiej Akademii Nauk.

Herbst, J. (2018). Nieocenione, niedocenione. Skala działań organizacji społecznych na wsi. In J. Wilkin, I. Nurzyńska (Eds.), Polska wieś 2018. Raport o stanie wsi (pp. 181-205). Warszawa: Wydawnictwo Naukowe Scholar.

Holmes, J. (2006). Impulses towards a multifunctional transition in rural Australia: gaps in the research agenda. Journal of Rural Studies, 22(2), 142-160. https://dx.doi.org/10.1016/j.jrurstud.2005.08.006

Holmes, J. (2012). Cape York Peninsula Australia: A frontier region undergoing a multifunctional transition with indigenous engagement. Journal of Rural Studies, 28, 252-265.

https://dx.doi.org/10.1016/j.jrurstud.2012.01.004 
Humer, A. (2018). Linking polycentricity concepts to periphery: Implications for an integrative Austrian strategic spatial planning practice. European Planning Studies, 26(4), 635-652. https://doi.org/10.1080/09654313.2017.1403570

Innicki, D. (2009). Statystyczna i rzeczywista przestrzeń instytucjonalna miasta. In T. Marszał (Ed.) Struktura funkcjonalna małych miast (pp. 115-137). Łódź: Wydawnictwo Uniwersytetu Łódzkiego.

Jepson, D., Sharpley, R. (2015). More than sense of place? Exploring the emotional dimension of rural tourism experiences. Journal of Sustainable Tourism, 23(8-9), 1157-1178. https://doi.org/10.1080/09669582.2014.953543

Jerkiewicz, A., Krawiec, K., Zagożdżon, A. (1979). Zmiany ludnościowe i osadnicze w Regionie Kłodzkim. Zeszyty Problemowe Postępów Nauk Rolniczych, 223.

Kairyte, E. (2015). Greater globalization challenges - lesser rural responses: The case of Alytus County, Lithuania. In J. McDonagh, B. Nienaber, M. Woods (Eds.), Globalization and Europe's Rural Regions, 107. Farnham: Ashgate. https://doi.org/10.4324/9781315585086

Kajdanek, K. (2009). Rozwój strefy podmiejskiej Wrocławia w perspektywie socjologii miasta: społeczna charakterystyka przestrzeni podmiejskich. In I. Jażdżewska (Ed.), Strefa podmiejska i małe miasta w okresie transformacji (23-32). Łódź: Wydawnictwo Uniwersytetu Łódzkiego.

Kajdanek, K. (2011). Suburbanizacja w Polsce - pejzaż społeczno-przestrzenny. Przegląd Socjologiczny, 60(2-3), 303-321.

Kajdanek, K. (2012), Suburbanizacja po polsku. Kraków: Nomos.

Kerckhof, A., Spalevic, V., Van Eetvelde, V., Nyssen, J. (2016). Factors of land abandonment in mountainous Mediterranean areas: the case of Montenegrin settlements. Springer Plus, 5, 485, 1-15. http://dx.doi.org/10.1186/s40064-016-2079-7

Kłosowski, F. (2017). Problemy z wykorzystaniem pracujących jako miernika rozwoju usług (przykład województwa ślaskiego). Space - Society - Economy, (13), 269-280. https://doi.org/10.18778/1733-3180.13.14

Konopińska, N. (2016). Negatywne procesy demograficzne charakteryzujące sudecki przygraniczny obszar górski. Ekonomia XXI Wieku, 1, (09), 151-159. https://doi.org/10.15611/e21.2016.1.09

Kościk, E. (1990). Osadnictwo wiejskie na Ziemi Kłodzkiej w latach 1945-1949. Acta Universitatis Wratislaviensis, 832, Historia, 53, 99-116.

Kościk, J. (1990). Przemiany demograficzno-osadnicze na Ziemi Kłodzkiej w XIX w. Acta Universitatis Wratislaviensis, 832, Historia, 53, 85-98.

Kučera, Z., Kučerova-Kuldova, S., Chromy, P. (2008). Landscape heritage between areal preservation and areal development - the case of Czechia. Geographia Polonica, 81(2), 5-23.

Kučera, Z., Chromý, P. (2012). Depopulation, resettlement and landscape changes in the peripheries of the Czech borderland. In A. Paniagua, R. Bryant, T. Kizos (Eds.). The political ecology of depopulation: Inequality, landscape and people (pp. 191-213). Zaragoza: Ceddar.

Kupková, L., Bičík, I. (2016). Landscape transition after the collapse of communism in Czechia. Journal of Maps, 12(1), 526-531. https://doi.org/10.1080/17445647.2016.1195301

Kutkowska, B. (2014). Rolnictwo dolnoślaskie 10 lat po akcesji do Unii Europejskiej. Prace Naukowe Uniwersytetu Ekonomicznego we Wrocławiu, (361), 139-151. https://doi.org/10.15611/pn.2014.361.14

Lang, T., Henn, S., Ehrlich, K., Sgibnev, W. (Eds.) (2015). Understanding geographies of polarization and peripheralization: Perspectives from Central and Eastern Europe and beyond. Basingstoke: Palgrave Macmillan.

Latocha, A. (2012). Changes in the rural landscape of the Polish Sudety Mountains in the post-war period. Geographia Polonica, 85(4), 13-21. https://doi.org/10.7163/GPol.2012.4.21

Latocha, A. (2013). Wyludnione wsie w Sudetach. I co dalej? Przeglad Geograficzny, 85(3), 373-396. https://doi.org/10.7163/przg.2013.3.3 
Latocha, A. (2015). Recovering the lost landscapes of abandoned villages in the Sudetes Mountains, southwest Poland. In V. Ivanišević, T. Veljanovski, D. Cowley, G. Kiarszys, I. Bugarski (Eds.), Recovering lost landscapes (pp. 45-56). Belgrade: Institute of Archaeology.

Latocha, A. (2016). Programy rolnośrodowiskowe a zmiany krajobrazu w Sudetach (na przykładzie powiatu kłodzkiego). Problemy Ekologii Krajobrazu, 43, 43-52.

Latocha, A. (2017). Odradzanie wsi? Przemiany ludnościowo-osadnicze na ziemi kłodzkiej w okresie powojennym. Studia Obszarów Wiejskich, 48, 29-50. https://doi.org/10.7163/SOW.48.3

Latocha, A., Szymanowski, M., Jeziorska, J., Stec, M., Roszczewska, M. (2016). Effects of land abandonment and climate change on soil erosion. An example from depopulated agricultural lands in the Sudetes Mts., SW Poland. Catena, 145, 128-141. https://doi.org/10.1016/j.catena.2016.05.027

Latocha, A., Szymanowski, M., Wieczorek, M. (2018). Wyludnianie powiatu kłodzkiego - przestrzenne zróżnicowanie i uwarunkowania. Przegląd Geograficzny, 90(2), 241-266. https://doi.org/10.7163/PrzG.2018.2.3

Larsen, K., Barker-Reid, F. (2009). Adapting to climate change and building urban resilience in Australia. Urban Agriculture Magazine, 22, 22-24.

Leimgruber, W. (2004). Between global and local. Marginality and marginal regions in the context of globalization and deregulation. Aldershot: Ashgate.

Li, Y., Westlund, H., Liu, Y. (2019). Why some rural areas decline while some others not: An overview of rural evolution in the world. Journal of Rural Studies, 68, 135-143. https://doi.org/10.1016/j.jrurstud.2019.03.003

MacDonald, D., Crabtree, J.R., Wiesinger, G., Dax, T., Stamou, N., Fleury, P., ... Gibon, A. (2000). Agricultural abandonment in mountain areas of Europe: Environmental consequences and policy response. Journal of Environmental management, 59(1), 47-69. https://doi.org/10.1006/jema.1999.0335

Mastalska-Cetera, B. (2006). Udział rolników w ochronie przyrody w Krajowym Programie Rolnośrodowiskowym na terenie Sudetów. In M. Furmankiewicz, P. Jadczyk (Eds.), Problemy współpracy na rzecz ekorozwoju Sudetów (pp. 129-144). Jelenia Góra - Wrocław: Muzeum Przyrodnicze w Jeleniej Górze, Akademia Rolnicza we Wrocławiu.

Mazur, M., Bański, J., Czapiewski, K., Śleszyński, P. (2015). Wiejskie obszary funkcjonalne - próba metodyczna wyznaczenia ich obszarów i granic. Studia Obszarów Wiejskich, 37, 7-36. https://doi.org/10.7163/sow.37.1

McLeman, R.A. (2011). Settlement abandonment in the context of global environmental change. Global Environmental Change, 21, 108-120. http://dx.doi.org/10.1016/j.gloenvcha.2011.08.004.

Miszczuk, A., Wesołowska, M. (2012). Demographic and settlement transformations in peripheral regions (based on the example of eastern Poland). Annales UMCS, Geographia, Geologia, Mineralogia et Petrographia, 67(1), 141-151. http://dx.doi.org/10.2478/v10066-012-0009-4

Miszewska, B. (1979). Tendencje zmian ludnościowych w Sudetach na przykładzie rejonu noworudzkiego. Czasopismo Geograficzne, 50(1-2), 75-86.

Miszewska, B. (1989). Zmiany zaludnienia Sudetów w okresie powojennym. Czasopismo Geograficzne, 60(2), 135-145.

Nørgaard, H. (2011). Futures of rural and peripheral areas: Challenges, strategies and policies. Landinspektoeren. Tidsskrift for kortlaegning og Arealforvaltning, 46(1), 81-95.

Organisation for Economic Co-operation and Development (OECD). (2006). The New Rural Paradigm: Policies and Governance.

Pelc, S. (2017). Marginality and marginalization, In R. Chand, E. Nel, S. Pelc (Eds.), Societies, social inequalities and marginalization. Marginal regions in the 21st Century (pp. 13-28). Springer International Publishing. https://doi.org/10.1007/978-3-319-50998-3_2 
Pénzes, J. (2013). The dimensions of peripheral areas and their restructuring in Central Europe. Hungarian Geographical Bulletin, 62(4), 373-386.

Pezzi, M.G., Urso, G. (2016). Peripheral areas: conceptualizations and policies. Introduction and editorial note. Italian Journal of Planning Practice, 6(1), 1-19.

Pinto-Correia, T., Guiomar, N., Guerra, C.A., Carvalho-Ribeiro, S. (2016). Assessing the ability of rural areas to fulfil multiple societal demands. Land Use Policy, 53, 86-96. https://doi.org/10.1016/j.landusepol.2015.01.031

Plewniak, W. (1978). Zmiany w środowisku geograficznym doliny Dzikiej Orlicy w Górach Bystrzyckich wywołane wyludnianiem wsi. Acta Universitatis Wratislaviensis, 324, Prace Instytutu Geograficznego, seria $B, 2,97-109$.

Plieninger, T., Draux, H., Fagerholm, N., Bieling, C., Bürgi, M., Kizos, T., ... Verburg, P.H. (2016). The driving forces of landscape change in Europe: A systematic review of the evidence. Land Use Policy, 57, 204-214. https://doi.org/10.1016/j.landusepol.2016.04.040

Potocki, J. (2009). Funkcje turystyki w kształtowaniu transgranicznego regionu górskiego Sudetów. Wrocław: Wydawnictwo WTN

Raczyk, A. (2009). Metody badania przedsiębiorczości oparte na rejestrze podmiotów gospodarki narodowej. In T. Zioło, T. Rachwał (Eds.), Rola przedsiębiorczości w kształtowaniu społeczeństwa informacyjnego (pp. 133-146), Warszawa - Kraków: Nowa Era.

Romano, B. (1995). National parks policy and mountain depopulation: A case study in the Abruzzo region of the central Apennines, Italy. Mountain Research and Development, 15(2), 121-132. https://doi.org/10.2307/3673876

Rosner, A. (2012). Zmiany rozkładu przestrzennego zaludnienia obszarów wiejskich. Wiejskie obszary zmniejszajqce zaludnienie i koncentrujacce ludność wiejska. Warszawa: Instytut Rozwoju Wsi i Rolnictwa PAN.

Salvatore, R., Chiodo, E., Fantini, A. (2018). Tourism transition in peripheral rural areas: Theories, issues and strategies. Annals of Tourism Research 68, 41-51. https://doi.org/10.1016/j.annals.2017.11.003

Salwicka, B. (1978). Zmiany w zaludnieniu i użytkowaniu ziem wsi górskich Masywu Śnieżnika w strefie granicy rolno-leśnej. Acta Universitatis Wratislaviensis, 324, Prace Instytutu Geograficznego, seria B, 2, 71-87.

Sánchez-Zamora, P., Gallardo-Cobos, R., Ceña-Delgado, F. (2014). Rural areas face the economic crisis: Analyzing the determinants of successful territorial dynamics. Journal of Rural Studies, 35, 11-25. http://dx.doi.org/10.1016/j.jrurstud.2014.03.007

Schmidt, M. (2007), Some reflections on the definition and delimitation of geographical marginality (Papers presented during the Commission Meeting 2001-2004). In G. Jones, W. Leimgruber, E. Nel (Eds.), Issues in Geographical Marginality, Grahamstown, South Africa: Rhodes University.

Serra, P., Vera, A., Tulla, A.F. (2014). Spatial and socio-environmental dynamics of Catalan regional planning from a multivariate statistical analysis using 1980s and 2000s data. European Planning Studies, 22(6), 1280-1300. http://dx.doi.org/10.1080/09654313.2013.782388

Shrinking regions: a paradigm shift in demography and territorial development. Study (2008). Brussels: European Parliament.

Sikorski, D. (2020). Organizacje pozarządowe w powiecie kłodzkim po 2000 roku. In A. Marek, Ziemia kłodzka w kulturze, architekturze i przyrodzie (pp. 147-167). Pelplin: Bernardinum.

Sikorski, D., Latocha, A., Szmytkie, R., Kajdanek, K., Miodońska, Tomczak, P. (2020). Functional changes in peripheral mountainous areas in east central Europe between 2004 and 2016 as an aspect of rural revival? Kłodzko County case study. Applied Geography, 122, 102223. https://doi.org/10.1016/j.apgeog.2020.102223

Skokanová, H., Faltáan, V., Havlíček, M. (2016). Driving forces of main landscape change processes from past 200 years in Central Europe-differences between old democratic and post-socialist countries. Ekológia, 35(1), 50-65. https://doi.org/10.1515/eko-2016-0004 
Sørensen, Jens, F.L. (2018). The importance of place-based, internal resources for the population development in small rural communities. Journal of Rural Studies, 59, 78-87.

https://doi.org/10.1016/j.jrurstud.2018.01.011

Stacherzak, A., Hełdak, M. (2013). Przemiany funkcjonalne obszarów wiejskich Dolnego Śląska w latach 1996-2010. Prace Naukowe Uniwersytetu Ekonomicznego we Wrocławiu, 320, 186-195.

Stacherzak, A., Hełdak, M. (2019). Borough development dependent on agricultural, tourism, and economy levels. Sustainability, 11(2), 415. http://dx.doi.org/10.3390/su11020415

Strijker, D. (2005). Marginal lands in Europe - causes of decline. Basic and Applied Ecology, 6(2), 99-106. https://doi.org/10.1016/j.baae.2005.01.001

Sukała, Ł., Dej, M. (Eds.) (2018). Odnowa wsi jako narzędzie rozwoju lokalnego. Ujęcie teoretyczne i praktyczne. Warszawa: Instytut Rozwoju Miast i Regionów.

Szmytkie, R. (2008). Nieistniejące wsie w Sudetach. In M. Kulesza (Ed.). Czas i przestrzeń w naukach geograficznych. Wybrane problemy geografii historycznej (pp. 225-242). Łódź: Wydawnictwo Uniwersytetu Łódzkiego.

Szmytkie, R. (2015). Wiejska baza noclegowa powiatu kłodzkiego. Zeszyty Naukowe Wyższej Szkoły Bankowej we Wrocławiu, 15(2), 245-260.

Szmytkie, R., Tomczak, P. (2015). Współczesne tendencje zmian ludnościowych i funkcjonalnych na obszarach wiejskich Ziemi Kłodzkiej. Studia Obszarów Wiejskich, 37, 181-194.

https://dx.doi.org/10.7163/SOW.37.11

Szmytkie, R., Tomczak, P. (2017). Revival of rural settlements in Kłodzko land. Geographia Polonica, 90(3), 319-333. https://dx.doi.org/10.7163/GPol.0097

Szmytkie, R., Tomczak, P. (2018). Rozwój działalności gospodarczej jako wyraz „odradzania się” wsi na ziemi kłodzkiej. Studia Obszarów Wiejskich, 49, 39-57. https://dx.doi.org/10.7163/SOW.49.3

Śleszyński, P. (2007). Szacowanie liczby i rozmieszczenia pracujących w Warszawie. Przegląd Geograficz$n y, 79(3-4), 401-433$.

Śleszyński, P. (2011). Oszacowanie rzeczywistej liczby ludności gmin województwa mazowieckiego z wykorzystaniem danych ZUS. Studia demograficzne, 2, 35-58.

Śleszyński, P., Komornicki, T. (2016). Klasyfikacja funkcjonalna gmin Polski na potrzeby monitoringu planowania przestrzennego. Przeglad Geograficzny, 88(4), 469-488.

http://dx.doi.org/10.7163/PrzG.2016.4.3

Tomaszewski, J. (1968). Zmiany ludnościowe w osiedlach sudeckich ze szczególnym uwzględnieniem powiatów Jelenia Góra i Bystrzyca Kłodzka. Problemy Zagospodarowania Ziem Górskich, 6, 163-192.

Vaishar, A. (2006). Regional periphery: What does it mean?. Europa XXI, 15, 7-12.

Vaishar, A., Zapletalova, J., Hubačíková, V., Dvořák, P. (2013). Contemporary development of peripheral parts of the Czech-Polish borderland: Case study of the Javorník area. Geographia Polonica, 86(3), 237-254. https://doi.org/10.7163/ GPol.2013.21

van Eupen, M., Metzger, M.J., Pérez-Soba, M., Verburg, P.H., van Doorn, A., Bunce, R.G.H. (2012). A rural typology for strategic European policies. Land Use Policy, 29(3), 473-482.

https://doi.org/10.1016/j.landusepol.2011.07.007

Ventura-Lucas, M.R., Marques, C., Martins, M.D.B., Fragoso, R. (2011). Portuguese agriculture and its role in multifunctional rural development. APSTRACT: Applied Studies in Agribusiness and Commerce, 5(1033-2016-84123), 39-46. https://doi.org/10.19041/APSTRACT/2011/1-2/5

Wesołowska, M. (2016). Depopulacja wsi - szansa czy zagrożenie dla przestrzeni wiejskiej? Studia KPZK, $167,250-273$.

Wesołowska, M. (2018a). Polarization of rural settlements in the Lubelskie voivodeship as a result of population changes. Barometr Regionalny, 16(2), 161-171.

Wesołowska, M. (2018b). Wsie zanikajace w Polsce. Stan, zmiany, modele rozwoju. Lublin: Wydawnictwo UMCS. 
Wesołowska, M., Flaga, M. (2018). Demographic and social degradation in the Lublin province as a peripheral area of East Poland. Bulletin of Geography. Socio-economic Series, 41(41), 7-27. https://doi.org/10.2478/bog-2018-0023

Więckowski, M. (2010). Tourism development in the borderland of Poland. Geographia Polonica, 83(2), 67-81. https://doi.org/10.7163/GPol.2010.2.5

Więckowski, M. (2013). Eco-frontier in the mountainous borderlands of Central Europe: the case of Polish border parks. Journal of Alpine Research, 101-2. https://doi.org/10.4000/rga.2107

Więckowski, M. (2018), Political borders under ecological control on the Polish borderlands. Geographia Polonica, 91(1), 127-138. https://doi.org/10.7163/gpol.0105

Wight, J.B. (1983). From centre/periphery to territory/function: John Friedmann in transition. In J.C. Hansen, J. Naustdalslid, J. Sewel (Eds.), Centre-Periphery Theory: Theory and Practice, Sogndal.

Wilczyński, R. (2008). Programy odnowy wsi w Polsce. In J. Wilkin., I. Nurzyńska (Eds.), Polska wieś 2008. Raport o stanie wsi (pp. 99-116). Warszawa: FDPA - Fundacja na Rzecz Rozwoju Polskiego Rolnictwa.

Woods, M. (2007). Engaging the global countryside: Globalization, hybridity and the reconstitution of rural place. Progress in Human Geography, 31(4), 485-507.

https://doi.org/10.1177/0309132507079503

Woods, M. (2013). Rural development, globalization and European regional policy: Perspectives from the DERREG project. Geographia Polonica, 86(2), 99-109. https://doi.org/10.7163/GPol.2013.11

Wolski, J. (2007). Przekształcenia krajobrazu wiejskiego Bieszczadów Wysokich w ciagu ostatnich

150 lat. Prace Geograficzne, 214. Warszawa: Instytut Geografii i Przestrzennego Zagospodarowania im. Stanisława Leszczyckiego PAN.

Wolski, O. (2017). Odnowa wsi jako przedmiot badań. Ewolucja i systematyzacja pojęcia. Wieś i Rolnictwo, 2(175), 119-146. https://doi.org/10.7366/wir022017/06

Wyposażenia miast i miejscowości wiejskich w podstawowe placówki i urzqdzenia w województwie wałbrzyskim (1988). Wojewódzki Urząd Statystyczny we Wrocławiu.

Zagożdżon, A. (1988). Kilka uwag o obszarach problemowych. In B. Jałowiecki (Ed.) Gospodarka przestrzenna, region, lokalność (pp. 137-147). Biuletyn KPZK PAN, 138. Warszawa: Państwowe Wydawnictwo Naukowe.

Zagożdżon, A. (1990). Wybrane problemy ludnościowe Sudetów na tle rozwoju regionalnego, Studia Komitetu Przestrzennego Zagospodarowania Kraju, Polska Akademia Nauk, (96), 95-111. 